\title{
The Role of FDI in Eastern Europe and New Independent States: New Channels for the Spillover Effect. ${ }^{1}$
}

\author{
Irina Tytell ${ }^{2}$, \\ Ksenia Yudaeva ${ }^{3}$
}

December 20, 2005

\begin{abstract}
Policymakers around the world introduce special policies aimed at attracting foreign direct investments (FDI). They motivate their decision by the spillover effect, which FDI have on domestic companies. Empirical literature so far has failed to find any robust evidence of this effect. In this paper, we make an attempt to explain this finding. Using data from Poland, Romania, Russia, and Ukraine, we demonstrate that not all FDI have positive spillover effects on domestic firms. Spillovers are positive only in the case of export-oriented FDI and, more generally, are driven by the more productive foreign companies. Moreover, effects of FDI on domestic firms are not limited to knowledge spillovers: exposure to foreign technologies alters the form of their production functions. Specifically, foreign entry is associated with higher capital intensity and lower labor intensity of domestic firms in relatively more developed countries, such as Poland, while the opposite is the case in the less developed countries, such as Russia. These results are subject to threshold effects: benefits are more likely to materialize once a relatively large stock of foreign capital is accumulated. Absorptive capacity of domestic firms plays a crucial role in reaping the benefits of FDI. Both, knowledge spillovers and production function changes, occur predominantly in the more educated and the less corrupt regions.

\footnotetext{
${ }^{1}$ The authors thank Sergei Golovan for outstanding research assistance. Financial support for this project, and access to the Amadeus database was provided by the EBRD. The views expressed in this paper are those of the authors and not necessarily those of the EBRD or of other institutions with which the authors are affiliated.

${ }^{2}$ International Monetary Fund. Irina Tytell was a visitor at the Center for Economic and Financial Research (CEFIR at NES) while parts of this paper were written.

${ }^{3}$ Director for Policy Studies, Center for Economic and Financial Research (CEFIR at NES), and Scholar in Residence, Carnegie Moscow Center.
} 
Foreign direct investments (FDI) are widely considered an important catalyst of economic development. Both economists and policymakers believe that FDI can improve host countries' technological capacities and manage rial style both because of the direct effect on the companies that receive FDI and because of the spillover effect on domestic companies in the same industry and in upstream industries through backward linkages. In order to strengthen these effects, governments of many developing and transition economies introduce special policies aimed at attracting FDI and/or enhancing spillovers and backward linkages. In particular, regulation of FDI became one of the key issues for many recently negotiated preferential trade agreements and bilateral trade agreements.

This political enthusiasm is not based on a rigorous economic theory and evidence, particularly where the spillover effect is concerned. The rationale for the direct effect of FDI on firms' productivity is that FDI can only be made if the investor has an advantage over local firms either because of superior technological knowledge or because of better managerial techniques, distributional network, etc. As a result, firms with FDI should usually be more productive than domestic firms. This prediction is supported by virtually all empirical studies conducted both for developing and developed countries. ${ }^{4}$ Empirical studies also show that multinational companies usually pay higher wages than domestic ones. Aizenman and Spiegel (2002) argue, however, that this phenomenon can partially be explained by the necessity for foreign-owned firms to use efficiency wages in the environment characterized by poor contract enforcement and high monitoring costs.

Theoretical justifications for the spillover effect are even weaker. Normally, empirical studies of spillovers are motivated by the reference to demonstration effect, and potential for labor turnover between foreign-owned and domestic firms. In the case of inter-industry spillovers, a theoretical justification of the demonstration effect and transfer of technologies to domestic suppliers was provided by Rodrigues-Clare (1996) and Markusen and Venables (1999). For intra-industry spillovers this argument remains non-formalized.

Empirical work on the demonstration effect is complicated by the fact that spillovers of technological and managerial techniques are not the only effect that foreign-owned firms can exert on domestic ones. Entry of foreigners increases competition, which can have a two-fold

\footnotetext{
${ }^{4}$ The survey of the literature is provided by Lipsey (2004), Lipsey and Sjoholm (2005).
} 
effect on domestic firms. On the one hand, foreign firms take away some of the market from domestic firms. In the case of increasing return technologies, domestic firms can become less efficient as a result. On the other hand, increased competition can push domestic firms to improve efficiency and increase their total factor productivity (TFP). This effect can also be considered a spillover. However, this spillover is a result of increased effort of workers or management, while knowledge spillovers, which we discussed in the beginning, is a positive externality. $^{5}$

Given the presence of effects that go in different directions, empirical findings on the spillover effect are mixed. ${ }^{6}$ An influential paper by Aitken and Harrison (1999) finds no or negative spillovers from foreign to domestic firms in Venezuela. At the same time, Kathuria (2000) finds positive spillovers in the "scientific" sector of Indian manufacturing and no spillovers in the non-scientific sector. A study by Kokko $(1994,1996)$ suggests that the economy and firm-level capacity to absorb technology is an important determinant of the spillover effect. This result is confirmed by Takii (2001) and Todo and Miyamoto (2002), who show that positive FDI spillovers are more pronounced in the case of firms that conduct their own R\&D. In addition, Blalock and Gertler (2002) show that plants with more educated workforce derive greater benefits from foreign presence. In the case of developed countries, which are supposed to have enough absorptive capacity, Perri and Urban (2004) find evidence of the VeblenGerschenkron effect, according to which spillovers depend on the technological gap between foreign and domestic firms. In developing countries the effect of the technological gap is unclear. In the case of Indonesian firms, for example, Takii (2001) finds a negative effect, while Sjoholm (1999) and Blalock and Gertler (2002) find a positive effect.

Most transition economies are middle-income countries known for their high level of education. Therefore, one can imagine that they have a sufficiently good capacity to absorb knowledge spillovers. Nonetheless, the evidence concerning intra-industry spillovers in such countries is also inconclusive. Yudaeva et al (2003) show that this effect is positive in the case of Russian firms, Javorcik and Spatareanu (2004) and Damijan et al (2003) find positive spillovers in Romania, while Djankov and Hoekman (2000), Konings (2001) Javorcik and Spatareanu

\footnotetext{
${ }^{5}$ This argument is proposed by Haskel, Pereira, and Slaughter (2002), who correctly point out that these two different types of spillovers have different welfare implications.

${ }^{6}$ A detailed survey of the spillover literature can be found in Lipsey (2002) and Blomstrom and Kokko (1998, 2003).
} 
(2004) and Damijan et al (2003) observe negative effects for some other Eastern-European countries. The results of Zukowska-Gagelmann (2000) shed some light on the nature of the difference: she finds negative spillovers for the most productive Polish firms, located in sectors with high levels of competition, and positive spillovers for less productive firms.

The econometric approach that is typically used to estimate the spillover effect is often criticized for ignoring endogeneity of capital and heterogeneity of both foreign and domestic firms (Keane (2005)). At the same time, to our knowledge, no paper pays attention to the fact that entry of foreign firms can influence not only productivity of domestic firms, but, more generally, their production functions. Technological upgrade due to the demonstration effect may be visible as a change in total factor productivity (TFP), but it can also reveal itself as a change in the production function, in particular, as a change in factor intensities. In this paper, we conduct a test for the potential effect of FDI on the production function of domestic companies.

We find that in Poland foreign presence is associated with higher capital intensity and lower labor intensity of domestic firms. In Romania and Ukraine this effect appears insignificant, but in Russia the situation is exactly the opposite: domestic firms are more labor-intensive and less capital-intensive in sectors and regions where foreign firms are abundant. We also find that the effect of FDI on the production function of domestic firms is weaker or non-existent in regions with relatively low educational level or high corruption. Interestingly, foreign presence tends to have a negative effect on the change in capital-labor ratios of domestic firms. In Poland and Romania, this effect is weaker in sectors and regions where foreign firms enjoy the dominant position, while in Russia the opposite is the case. These findings point to potential threshold effects: as foreign firms get established in host countries, they force domestic firms to adjust in ways that depend on economic circumstances of individual countries. Thus, we see more beneficial effects in Poland, which is more developed, more open, has better institutions, and, consequently, attracts more FDI, than in Russia, which lags behind in these respects.

We find little evidence of the spillover effect on TFP of domestic firms, given unchanged production functions. However, we find positive and significant spillovers from export-oriented FDI in Russia (the only country for which we have these data). It has recently been argued in the literature (see Moran (2005)) that export-oriented foreign firms are better equipped to generate positive spillovers for domestic firms, than those attracted to protected domestic markets. The reason is that to be competitive in the international market, export-oriented foreign companies 
have to use cutting-edge production technologies, while those aiming to supply protected domestic markets tend to use knocked-down component kits and second-rate manufacturing processes. Our results support this view. We also find, more generally, that productivity of domestic firms tends to increase where foreign firms are more productive. In Poland and Romania, more productive FDI are also associated with higher capital-labor ratios of domestic firms after one year. These results suggest that not only the "quantity", but also the "quality" of FDI matters for the spillover effects on domestic firms.

The paper is organized as follows. In the next section we describe our data and provide the motivation for our choice of countries. In the second section we present the results of our baseline static estimations. In the third section we introduce differences in the institutional and educational environment, and in the forth section we explore dynamic settings. The final section concludes.

\section{The Data}

We chose four most populous countries of Eastern Europe for our analyses: Russia, Ukraine, Poland, and Romania. Besides being the largest in the region, these countries represent a wide spectrum in terms of their macroeconomic performance and institutional development. Table 1 contains a number of economic indicators for these countries, which we selected as potentially relevant to enterprise performance.

Poland is currently the richest of the four. Poland, however, has by far the highest rate of unemployment, while also the lowest rate of inflation. The Polish private sector enjoys the most domestic credit and the Polish government is ranked by far the best in terms of general effectiveness and the rule of law, and the lowest corruption level. However, the cost of starting a business and enforcing contracts is fairly high. The cost of starting a business is the lowest in Romania, where, interestingly, enforcing contracts is costly and where the private sector gets the least domestic credit. The Romanian labor market is fairly inflexible, especially on the hiring side, and highly educated workers are in relatively short supply. On the firing side, the least flexible market is in Ukraine, which is also the poorest of the four countries. Ukraine ranks lowest on government effectiveness and the rule of law and the cost of starting a business and corruption there is high. However, the cost of enforcing contracts is relatively moderate in 
Ukraine and also in Russia. The cost of starting a business in Russia is not too high and the labor market there is quite flexible. The Russian stock market, notably, is the most developed among the four countries. Yet, Russia ranks very low in terms of the rule of law, where it is on par with Ukraine. Its corruption level is on par with Romania, and in between Poland and Ukraine. Russia and Ukraine are also much less open to trade and foreign investment, than Poland and Romania.

We use firm level data for manufacturing companies in these countries for several recent years. Our data come from two sources: the national statistical authorities in the case of Russia and Ukraine and Amadeus database of Bureau van Dijk in the case of Poland and Romania. The data for Russia and Ukraine cover large and medium-sized industrial enterprises, while the data for Poland and Romania include also some smaller manufacturing firms. ${ }^{7}$ Table 2 gives a sense of coverage and the degree of foreign participation. ${ }^{8}$ Companies with foreign ownership are defined here as those with at least $10 \%$ owned by external entities, excluding those registered in popular off-shore destinations. This correction is important in our view, as the latter are likely domestic companies and therefore should be regarded as potential destination for, rather than source of, spillovers. In the case of Ukraine we also excluded companies owned by Russians or representatives of other New Independent States (NIS). These countries share a common past, and, therefore, technological level and managerial quality in Ukraine, Russia and other NIS is roughly equal. Our primary interest in this paper is spillovers from foreign companies to the domestic ones, which originate because of differences in technological levels and managerial practices. Given similarities between NIS, such spillovers between companies from these countries can only be very small.

The company data on Russia, Poland and Romania include turnover, material costs, fixed capital, and the number of employees, in addition to ownership information. In the Russian data material costs are reported as percentage of turnover. In the case of Ukraine, information about fixed capital and material costs is absent. Instead of value added in the Ukrainian regressions we use real output. Hence, the results for Ukraine are not directly comparable with the results for other countries. We define value added for each company as turnover minus material costs. For

\footnotetext{
${ }^{7}$ For Poland and Romania, we used the data for Amadeus top 1,5 million firms, which include firms that satisfy at least one of the following size criteria: operating revenue equal to at least $€ 1$ million, total assets equal to at least $€ 2$ million, number of employees equal to at least 15 .

${ }^{8}$ In what follows, we use fewer companies than appear in Table 2, as some of them were missing the necessary balance sheet items. Also, we cleaned the data of outliers, identified as those with value added, labor, and capital in either the top or the bottom percentiles (we did this for both the levels and the growth rates of these variables).
} 
lack of industry specific deflators, the balance sheet data in Poland, Romania and Ukraine are expressed in current US dollars. In Russia they are deflated with industry-specific deflators. An important caveat concerning our ownership information is that Amadeus provides only the latest available shareholder data for each company. Therefore, in the case of Poland and Romania we have to assume that ownership remained unchanged during the sample period. This assumption should be kept in mind when interpreting our results. ${ }^{9}$

Poland, Romania and Ukraine use the same industrial classification NACE, while Russian OKONH classification, which was used during the period under consideration, is very different. For each Russian firm, however, we have a list of activities that it performs. This list of activities uses a classification, which is very similar to NACE. The only problem is that there are several activities listed for each firm. We use the first activity from the list, considering it the primary activity. We exclude a number of firms that listed a non-manufacturing occupation as their major NACE ind ustry. For both Russia and Ukraine we have information not only on manufacturing industries, but also on some natural resource extracting industries. In what follows we exclude such industries for consistency with our data for Poland and Romania. ${ }^{10}$

\section{Static Specification}

We begin by estimating a Cobb-Douglas production function for each country, including a dummy variable for firms with foreign participation. We allow the factor shares to vary between domestic enterprises and those with foreign ownership. This simple specification allows us to compare productivities and factor intensities of domestic firms and those with foreign capital. Our results presented in Table 3 show that companies with foreign direct investment (FDI) are significantly more productive than domestic firms. The size of the coefficient on FDI dummy is the largest in Russia and the smallest in Poland. In Russia, companies with foreign participation enjoy an efficiency premium of about 70 percent, while in Poland this premium is just 9 percent

\footnotetext{
${ }^{9}$ Assuming that foreign participation in these countries grows over time, we probably count some companies, in which foreigners acquired stakes during our sample period, as partly or wholly foreign owned throughout. We may, therefore, overstate the foreign presence in the earlier years and, consequently, dilute the technological and managerial superiority of companies with foreign ownership over domestic firms. We think, however, that the resulting downward bias on the spillover effect is relatively small, since companies tend to change ownership only infrequently.

${ }^{10}$ We experimented with the inclusion of these industries and found that this does not change our qualitative results.
} 
(in fact, the coefficient on FDI is not statistically significant in the case of Poland). These are very large productivity differences.

A simple comparison of average labor productivities in Russia and Poland suggests that the observed variation in the efficiency premium is due in a large part to differences in productivity of domestic firms. While both domestic firms and firms with FDI are more productive in Poland than in Russia, domestic firms are 2.2 times more productive and firms with foreign ownership are only about 1.7 times more productive. Interestingly, a comparison between Russia and Romania suggests a rather different story. Both, domestic firms and firms with FDI, are more productive in Russia, than in Romania, but domestic firms are just 1.7 times more productive, while firms with foreign ownership are 2.9 times more productive. In this latter case, therefore, the variation in the efficiency premium is due largely to differences in productivity of firms with FDI.

Companies with FDI are also somewhat less labor intensive and somewhat more capital intensive. The differences are particularly striking in Russia, where companies with FDI have labor intensity that is 42 percentage points lower and capital intensity that is 27 percentage points higher than those of domestic firms. For comparison, in Poland and Romania the difference in labor intensity does not exceed 7 percentage points and the difference in capital intensity is between 4 and 5 percentage points. In both Russia and Ukraine domestic companies are extremely labor intensive, with labor elasticities exceeding 1, which distinguishes them sharply from firms in Poland and Romania. While this may reflect issues with capital valuation, it could also point to severe problems of depreciation and obsoleteness of the capital stock in these countries. Labor hoarding or the wide-spread use of part-time workers in Russia and Ukraine may be an additional explanation of this phenomenon.

In order to study the potential spillover effects of firms with foreign participation on domestic companies, we constructed the following measure of density of firms with FDI:

$$
\text { FDI DENSITY }=\frac{\sum_{t, s, r}(L \cdot F D I)}{\sum_{t, s, r} L} .
$$

FDI in the formula stands for the share of foreign ownership that ranges from 0.1 to 1 , while $\mathrm{L}$ denotes the number of employees. FDI DENSITY measures the weighted labor employed in firms with foreign capital, relative to the total labor employed in a given year, sector, and region. 
This is a measure of foreign presence that is standard in this literature. It allows us to study horizontal spillovers, i.e. those to enterprises within the same industry. Since we use two-digit industries to define sectors, this measure also captures some vertical spillovers, i.e. those to enterprises in upstream industries. In addition, it reflects the likely local nature of spillovers in countries with yet not fully developed business communication networks.

On average, density of firms with FDI is just over 20 percent in Poland and Romania, while it is not even 10 percent in Russia and Ukraine. It is possible that the effects of FDI on domestic firms change as FDI accumulate. As more foreign capital flows in, foreign firms may become more inclined to introduce more advanced technologies. This may happen for a number of reasons. Foreign firms may become more familiar with local conditions, and, therefore, more confident in bringing in more advanced technologies. Competition among foreign firms themselves may create additional incentives to use the most recent technologies. They may also become more familiar with local producers and trust them with production of more sophisticated components. If this is the case, one would expect to see more positive spillovers in Poland and Romania, than in Russia and Ukraine.

Table 4 provides a breakdown of FDI DENSITY by industrial sector for each country. Interestingly, there is quite a significant difference between industrial composition of FDI in Russia and Ukraine on the one hand, and Poland and Romania on the other. Among manufacturing sectors, there is strong correlation (about .30) in FDI DENSITY between Poland and Romania, and even stronger correlation (about 0.86) between Russia and Ukraine. However, across these two groups of countries correlations are much smaller: FDI DENSITY by sector in Poland or Romania is correlated with that in Russia with the coefficient of 0.02-0.03 and with that in Ukraine with the coefficient of 0.13-0.17.

High correlations in FDI DENSITY by sector within our two country groups suggest that foreign capital tends to favor or avoid roughly the same industries in countries different in many respects, yet united by their belonging to transition economies of either Eastern Europe or the NIS. Low correlations between the two groups, however, point to differences in attractiveness of various manufacturing sectors for foreign investment in Eastern Europe versus the NIS. Eastern European countries attract FDI into relatively more capital intensive and high-tech sectors: communication equipment, electrical equipment, and production of motor vehicles seem to attract a lot of FDI in both Poland and Romania. In contrast, in the NIS FDI go into natural 
resource processing industries, such as basic metals or paper, rather than into technologically intensive production of communication equipment. It is interesting to notice also that foreign presence in production of tobacco is high in all four countries, and in Russia, Romania and Poland there is a large share of foreign employment in the wood industry. In contrast to Poland, where foreign share is relatively big in some of the machine building sectors and furniture, in Romania foreign companies are common in the light industry, i.e. textile, apparel, and leather.

Such composition of investments may reflect comparative advantage, but can also be a result of institutional differences. During the period under consideration, both Poland and Romania were EU accession countries, while EU accession of Russia and Ukraine is not on the agenda. Therefore, foreign investors may consider Poland and Romania as a cheap labor export platform to the EU, while due to poor institutional quality and higher barriers to trade with the EU Russia and Ukraine can only be considered as natural resource suppliers for the European market. Being relatively big countries, Russia and Ukraine can also attract FDI aimed at supplying the domestic market. Investments into car assembly in these two countries can fall into this category, while similar investments in Poland can aim at supplying not only Polish, but also the EU market. According to Moran (2005), who argues that export-oriented foreign entrants bring with them better technologies and therefore are more likely to generate positive spillovers, one would expect to see more positive spillovers in Poland and Romania, than in Russia and Ukraine.

We proceed to search for the potential spillovers to domestic companies using the following general specification (estimated for domestic firms only):

$$
\ln V A_{i, t}=\alpha+\beta_{L} \ln L_{i, t}+\beta_{K} \ln K_{i, t}+\gamma \text { FDI DENSITY } \operatorname{DEN}_{t, r}+\varepsilon_{i, t} .
$$

We estimate this equation, first, using the data averaged by year, sector, and region, second, controlling for year and firm fixed effects and, third, allowing for some heterogeneity in the production function. The first approach gives a sense of how the presence of fully and partially foreign-owned firms is associated with local sectoral productivity. The second approach takes into account firm heterogeneity and, therefore, alleviates potential biases that could result from ignoring it. Finally, the third approach allows differences in the production function by sector, as well as depending on the degree of local foreign presence in the sector, in addition to firm fixed effects. The three estimations are reported, respectively, in Panels A, B, and C of Table 5. 
In the first specification (Panel A) for Russia and Ukraine, the coefficient on FDI DENSITY is positive and statistically significant, while for Poland and Romania, this coefficient is negative and statistically significant for Romania, although not for Poland. These results suggest that foreign capital in Russia and Ukraine tends to flow to sectors and regions where domestic firms are more productive. However, in Poland and Romania firms with foreign participation tend to concentrate in relatively unproductive sectors and regions.

In the second specification with firm fixed effects (Panel B) the coefficient on FDI DENSITY is positive but statistically insignificant for all the countries, except Russia, where it is negative and insignificant. This result suggests that, generally, there is no evidence for spillover effects from foreign direct investment on productivity of domestic firms. This finding is in agreement with most of the recent empirical literature on FDI spillovers.

In the case of Poland, however, the positive spillover effect is borderline significant at $12 \%$ level, which may be due to simultaneity that affects both domestic firms and firms with foreign capital, above and beyond firm-specific fixed effects. To control for this possibility, we constructed an instrumental variable for FDI DENSITY equal to the average FDI DENSITY in the same sector across similar neighboring countries. As we noted above, there is a fairly strong correlation of FDI DENSITY by sector across countries of Eastern Europe. Yet, average FDI DENSITY of other countries is likely exogenous with respect to performance of domestic firms, which makes it a suitable instrument. We used data from Amadeus on Bulgaria, the Czech Republic, Croatia, Estonia, Latvia, and Lithuania, all relatively small economies and therefore unlikely to influence firm performance elsewhere. Our results (see Table 6) demonstrate that controlling for potential simultaneity makes the coefficient on FDI DENSITY completely statistically insignificant and, in fact, negative.

As we already mentioned, the recent literature started to pay more attention to heterogeneity of FDI and, in particular, to potential differences in spillovers on domestic firms from exportoriented FDI and FDI aimed at supplying domestic markets (Moran (2005), Melitz (2005)). We tested this hypothesis for Russia, the only country for which we have the necessary data. Using a dataset on international trade transactions, we identified those foreign firms that exported more than 50 percent of their output. We computed a measure of EXPORT-ORIENTED FDI DENSITY as a share of such firms in the total employment in each year, sector, and region, weighted by the size of the foreign stake. The coefficient on EXPORT-ORIENTED FDI 
DENSITY turned out to be positive and significant in the fixed effects specification (see Table 7), while that on FDI DENSITY became negative and statistically insignificant. This result supports the idea that the positive spillover effect on productivity originates from export-oriented FDI, if at all.

In the third specification (Panel C) we allow production functions to be different across sectors and to be influenced by FDI DENSITY. After all, it is reasonable to expect that if foreign presence has any effect on domestic firms, it is unlikely to be limited to productivity. Rather, technological spillovers should affect the production function of domestic firms, in particular, the factor intensities. If domestic firms become more technologically sophisticated as a result of their contact with foreigners, their production processes are likely to become more capital intensive and less labor intensive. This is, indeed, the case in Poland. In this country, in sectors with 10 percent local foreign ownership capital intensity of domestic firms is over 2 percentage points higher and labor intensity is over 3.5 percentage points lower than elsewhere. In Romania the difference in intensities is not statistically significant, but domestic firms appear somewhat less labor intensive where the density of foreign firms is higher. For Ukraine we do not have data on capital, but labor intensity of domestic firms also appears to be smaller in sectors and regions with substantial foreign presence, although the difference is not significant. Surprisingly, the results for Russia are absolutely different: domestic firms are more labor-intensive and less capital intensive in sectors that attract a lot of FDI. ${ }^{11}$

Our findings on the production function effects in Russia and Poland may reflect backward linkages between domestic and foreign firms. There is anecdotal evidence suggesting that if foreign firms work with Russian suppliers, then these suppliers are producers of technologically simple and often labor intensive goods. Ford, for example, assemble s cars in Russia using imported components, with the exception of a few components made of rubber. Poland, on the other hand, has a longer history of FDI inflows, giving domestic producers of the same goods time to upgrade their technologies to more capitalintensive processes. Additionally, foreign investors in Poland may have become more familiar with local producers and may, therefore, trust them with production of some capital-intensive components. An alternative and complementary explanation of our findings is that competition from foreign firms forces

\footnotetext{
${ }^{11}$ We cannot, at this stage, fully exclude the possibility of reverse causality, i.e. that foreign companies are attracted to more capital intensive and less labor intensive parts of the domestic economy in Poland, and to less capital intensive and more labor intensive parts of the domestic economy in Russia. We return to this issue below.
} 
domestic firms to adjust in ways that depend on the situation in their particular country. Thus, while Polish firms upgrade their capital and technologies in order to compete in the same market with foreign entrants, Russian firms shield themselves from foreign competition by concentrating on producing unsophisticated labor-intensive goods for the less well-off segments of the population.

To summarize, we find that firms with foreign capital are significantly more productive than domestic companies in all four countries. However, we find no evidence for productivity spillovers (whether positive or negative) in all the countries, however different they are. The only exception to this finding is export-oriented FDI, which generate positive spillover effects on productivity of domestic firms in Russia. Our results suggest that spillover effects may manifest themselves in changes in the production functions of domestic firms, rather than simply in the higher TFP. Domestic firms in Poland are more capital-intensive and less labor-intensive where FDI are more abundant, while the reverse is true in Russia. In other words, we observe more beneficial effects in a country that has a larger foreign presence and that is more open to foreign trade, which is consistent with our expectations.

\section{The Role of Education and Institutions}

External factors, such as the endowment of skills, measured by the education level in the host country, and the quality of the host country's institutions, can influence both the choice of technologies used by foreign investors and the capacity and incentives of domestic firms to learn from their foreign competitors. In this section we look at the effects of education and corruption on productivity of foreign firms and on the spillovers that they impart on domestic firms.

Formally, the education level in all the countries that we consider is quite high: for example, in Russia, according to the latest population census, about $77 \%$ of the population has at least secondary education; in the Ukraine, Poland, and Romania the proportion is comparably high. ${ }^{12}$ However, educational achievement of the local population differs substantially from region to

\footnotetext{
12 There are several reasons why this formal measure of educational achievement may overestimate the true level of education and skills. First of all, a number of studies have demo nstrated that students from transition countries, such as Russia, often have problems with practical implementation of their knowledge to non-standard tasks. Secondly, there is anecdotal evidence that the quality of education has declined after the beginning of transition, at least in Russia. Unfortunately, there are no measures of quality, rather than just "quantity" of education.
} 
region within a country. ${ }^{13}$ We use this regional variation to study how local educational levels influence the domestic impact of foreign firms. We divided all regions within a country into three equally-sized groups: those with low, average, and high share of the population with at least secondary education. We then estimated the key specifications of the previous section for two sub-groups of firms: those located in the low-education regions and in the high-education regions. ${ }^{14}$

We begin by considering the direct effect of foreign presence. Differences in education may influence both the decision of foreign firms to locate in a certain region and their choice of technologies. In Table 8 we report estimations of the same model that we used in Table 3 separately for firms in the low-education regions and those in the high-education regions. The results show that in Russia the difference between the firms located in different regions is not very significant, although the productivity gap between domestic and foreign firms is somewhat larger in the less educated regions. Therefore, differences in education either have no influence on the behavior of foreign direct investors, or influence only their location decision in this country. In Ukraine, productivity differences between foreign and domestic firms are more pronounced in the regions with better educated labor force. This finding suggests that in Ukraine foreign firms have advantages in those regions, where they have access to the labor pool of a better quality. In Poland, firms with foreign participation are dramatically more productive than domestic firms in the less educated regions, while they are on the par with domestic firms in the more educated ones. At the same time, foreign firms in the less educated areas operate using the same production function as domestic firms, while those in the more educated areas are substantially more capital intensive than domestic firms. A possible explanation is that while both domestic and foreign firms produce similar goods in the less educated areas, in the more educated areas domestic firms produce less technologically adva nced goods than their foreign counterparts, but are just as productive in what they do. In Romania, the overall difference in productivity between domestic and foreign firms is almost the same irrespective of the educational level of the area, while the production function differences are more pronounced in the less educated regions. This would be consistent with a situation, in which domestic firms in

\footnotetext{
${ }^{13}$ Information about educational levels was obtained from the Population Census of respective countries.

${ }^{14}$ The relative share of foreign firms in the low-education and the high-education regions was similar.
} 
the poorly educated parts of the country produce very low technology goods, while those in the more educated regions are more similar to foreign firms in the nature of their production.

Several studies (Blalock and Gertler, 2003, Yudaeva et al , 2003) suggest that ability of domestic firms to absorb knowledge spillovers may depend on the educational level of the population. We proceed by using cross-regional differences to test the hypothesis of the importance of education for spillovers. We estimated our spillover model separately for firms in the low-education regions and those in the high-education regions. In this specification we allowed factor intensities to vary by industry and to depend on the density of foreign companies in the same sector and region. The results (Table 9) show no evidence for productivity spillovers irrespective of the educational level of the local population, with the exception of Ukraine where we observe positive spillovers only in high-education regions. There is, however, some evidence that the effect of foreign presence on the production function of domestic firms in Poland and Russia differs depending on the educational attainment. In the less educated areas of both countries production functions of domestic firms do not depend on FDI density in the same region and industry. Differences, reported earlier, are concentrated in highly educated regions. In the more educated areas of Poland domestic firms are less labor intensive and more capital intensive where the density of foreign firms is higher. (We observe a similar effect in the case of Ukraine, but given the absence of data on capital, this finding should be treated with caution.) In Russia the situation is exactly the opposite: domestic firms in the more educated areas are more labor intensive and less capital intensive where the density of foreign firms is higher. These results suggest that education, which can be regarded as a proxy for absorptive capacity, is the major pre-condition for spillover effects on productivity or on production functions.

The study by Yudaeva et al. (2003) demonstrated that in Russia in the early years of transition, policies of regional authorities had a significant influence on the productivity of foreign firms. It is interesting to check whether this effect is still present in the more recent period. Unfortunately, the measures of government reform orientation that were used in Yudaeva et al. (2003) are not available for recent years or for other countries. Instead, we use a measure of the perception of corruption, which has recently been reported by INDEM, a Russian anticorruption think tank. This measure is available for 40 Russian regions, and is constructed using the results of a survey of households and businesses in these regions. As in the case of education, we test for the effect of corruption by estimating our regression equations in the sub-samples of 
regions with high and with low levels of corruption. As a corruption index we used integrated index of corruption, reported at http://www.indem.ru.

Consistently with the findings of Yudaeva et al. (2003), foreign firms are more productive than domestic ones in the regions with low corruption (Table 10). In the high-corruption regions there are no differences in productivity between domestic and foreign firms. This result seems to contradict our earlier finding that productivity gap in Russia is higher than in Poland, which is less corrupt. However, at the country level this difference may be due to other factors. Poland is not only less corrupt than Russia, but also more open, has more FDI, and is generally more advanced.

We also tested for the presence of knowledge spillovers in high and low corruption regions (Table 11). FDI DENSITY is insignificant in high-corruption region, and negative and significant in low-corruption regions. As shown in Table 10, foreign firms in the regions with low corruption are more than twice as productive as domestic firms. Such a large productivity difference could result in crowding out of local domestic firms. The overall effect on welfare can still be positive, because foreign-owned firms are so much more productive than domestic ones. There also seems to be a difference between low and high corruption regions in the effect of FDI DENSITY on the production function of domestic firms. The coefficient on the cross term between the log of labor and FDI DENSITY is positive and significant only in low corruption regions, while in high corruption regions this coefficient is positive, but insignificant. Therefore, domestic firms react to foreign entry by switching to more labor-intensive technologies only if the corruption level is low. This may be an adjustment that Russian firms make in order to compete with highly productive foreign-owned firms. By switching to more labor-intensive technologies and producing goods of low quality but at cheaper costs, domestic firms find their niche as producers for less well-off consumers. Additionally, some domestic firms may become suppliers for foreign-owned firms, and, as we argued before, labor-intensive firms can have higher chances to be accepted by foreign firms as their suppliers. The lack of any effects in the high-corruption regions is consistent with the following interpretation. Domestic firms in these regions use their connections with the local authorities to put administrative pressure on foreignowned firms, which reduces their effectiveness. This practice reduces the competitive pressure from foreign-owned firms, which, in turn, reduces the incentives of domestic firms to adopt new technologies. 
To summarize, we show that the effects of education on the characteristics of foreign investors do not follow any single pattern across the four countries that we study. Only in Ukraine productivity spillovers from FDI depend positively on education. Results for Russia and Poland suggest that education may play a role in facilitating the effect of foreign presence on the production function of domestic firms. Ins titutional environment, measured by the corruption level, has a more complicated effect on foreign and domestic firms. Productivity of foreign firms located in more corrupt environments is not significantly different from productivity of domestic firms. However, foreign firms located in relatively low-corruption regions are much more productive than domestic firms. As a result, productivity spillovers on domestic firms are negative, and domestic firms have to change their production function to allow them to compete better or to work as suppliers for foreign firms. Both the production function and the productivity spillover effects, are absent in highly corrupt regions.

\section{Dynamic Specification}

We now go beyond the static specification to analyze whether and how foreign presence affects the change in, rather than merely the level of, productivity of domestic firms. The dynamic panel estimation that we use allows us to control for potential endogeneity of FDI DENSITY by instrumenting it using past values. The dynamic specification also allows us to include, in addition to the density of foreign firms, a measure of the ir productivity. Our results for Russia reported above (see Table 7) suggest that export-oriented foreign firms generate stronger spillovers, presumably because they use more advanced technologies in order to compete in the international market. This finding raises a more general question: do more productive foreign companies exert a stronger spillover effect on domestic firms? This is a natural question to ask, yet it has not received much attention in the existing literature.

We measure total factor productivity (TFP) of individual firms as a residual from a fixed effects estimation of the Cobb-Douglas production function, with factor shares that are allowed to vary by industrial sector. ${ }^{15}$ We then aggregate our measure to obtain average TFP of firms

\footnotetext{
${ }^{15}$ We experimented with an alternative measure of TFP based on stochastic frontier estimation, again with factor shares that vary by sector. Effectively, the stochastic frontier approach allows for firm fixed effects with industryspecific estimated growth trends. However, we encountered convergence problems when running these estimations
} 
with foreign ownership in each sector and region in a given year (FDI TFP). We study dynamic effects of FDI TFP and FDI DENSITY using the following specification:

$$
\operatorname{TFP}_{i, t+1}=\alpha \operatorname{TFP}_{i, t}+\beta F D I \text { TFP }_{t, s, r}+\gamma \text { FDI DENSITY } Y_{t, s, r}+\varepsilon_{i, t}
$$

We estimate this equation only for domestic companies using the system GMM method of Blundell and Bond (1998). This method estimates a system of equations in levels and first differences using as instruments, respectively, lagged first differences and lagged levels of endogenous variables (as well as lags and leads of exogenous variables). In a model with a lagged dependent variable this approach is superior to ordinary least squares, which causes an upward bias, and to the fixed effects estimator, which produces a downward bias in the coefficient $a$. This method also tends to perform better than the difference GMM approach of Arellano and Bond (1991), which is based on equations in first differences only, especially in the case of persistent series when lagged levels provide weak instruments for subsequent first differences.

Table 12 displays our results. We observe from Panel A that productivity of foreign firms is indeed positively associated with productivity of domestic firms in the same sector and region in the following year. The coefficient on FDI TFP is positive for all four countries and statistically significant for Russia and Romania. In other words, productivity of domestic firms tends to grow where firms with FDI are more productive. This finding is in contrast with the effect of merely foreign presence: the coefficient on FDI DENSITY is negative in three out of four countries and statistically significant in Romania. Thus, it appears that foreign entry slows productivity growth of domestic firms, possibly because they lose market share yielding to increased competition.

We argued above that effects of foreign presence may change as foreign capital accumulates. Namely, foreign firms may initially focus on labor-intensive activities in order to benefit from low labor costs in the host count ries, but shift to more advanced technologies as their weight and experience in the area grows. They may also be unwilling initially to outsource high-technology jobs to local producers, but as they invest more in their relationship with domestic firms, they may trust the locals with production of more sophisticated components. We incorporate this potential threshold effect into our analysis by adding a variable that equals FDI DENSITY if the latter exceeds 50 percent, and zero otherwise. Our results reported in Panel B show that the 
coefficients on FDI DENSITY and FDI DENSITY over 50\% are of different signs in three out of four countries. Both are statistically significant in Romania, where the productivity-reducing effect of foreign presence in much smaller in sectors and regions where foreign firms dominate (-0.366 as compared to -1.052). This is consistent with our notion of threshold effect, although the spillover effect in FDI-abundant sectors and regions is still negative. It is possible that it takes not only large foreign presence, but also a longer period to see any positive spillover effect, but, unfortunately, our panel is too short to tell. Interestingly, the signs on FDI DENSITY and FDI DENSITY over 50\% are reversed in Russia, although both are statistically insignificant.

Our results above (see Table 5, Panel C) suggest that the effect of foreign entry may manifest itself in the change of the production function of domestic firms, rather than simply in higher total factor productivity. To examine this issue in a dynamic setting, we look at the effects that foreign presence and foreign productivity have on the capital-labor ratio of domestic firms:

$$
\log (K /)_{i, t+1}=\alpha \log (K /)_{i, t}+\beta F D I \operatorname{TFP}_{t, s, r}+\gamma F D I D E N S I T Y_{t, s, r}+\varepsilon_{i, t}
$$

The outcome of our estimations is reported in Table 13. For Poland and Romania, Panel A shows that higher productivity of foreign companies is associated with higher capital-labor ratios of domestic firms in the same sector and region in the following year. This is consistent with the idea that more productive foreign firms generate more pronounced positive effects on domestic firms. Higher density of foreign companies, however, is associated with lower capital labor ratios in the following year in both countries. This is consistent with the notion that foreign entry, rather than driving technology transfer, forces domestic firms to compete by focusing on cheaper low-technology goods for the less well-off segments of the domestic population. This finding does not necessarily contradict the results we obtained above using a static specification (see Table 5, Panel C). Since in the dynamic regressions we control for the productivity of foreign firms, our measure of their density is largely divorced from their efficiency. While highly efficient foreign entrants are a possible source of knowledge spillovers, the sheer number of foreign firms affects domestic producers most likely through increased competition. An alternative explanation would suggest that our static results reflect reverse causation. In other words, foreign companies in Poland and Romania are attracted to more capital-intensive segments of these economies, but once they establish there, they drive domestic firms into more labor-intensive activities. In Russia, neither FDI TFP, nor FDI DENSITY is significantly 
associated with the change in productivity of domestic firms. Ukraine is excluded from these estimations due to the lack of data on capital.

It is possible that the effect of foreign presence on the capital labor ratios of domestic firms is also subject to threshold effects. To test this proposition we again included FDI DENSITY over $50 \%$ in the regressions (Panel B). In the case of Poland and Romania, the negative effect appears weaker for those firms located in sectors and regions where companies with foreign ownership dominate (-0.515 versus -1.638 in Romania). This finding supports our threshold hypothesis: as the weight of FDI increases, foreign firms bring in more advanced technologies and/or outsource the production of more capital-intensive parts to local firms. In Russia, however, the negative effect seems to be driven by the more FDI-abundant sectors and regions. This may be related to our earlier finding (see Table 5, Panel C) that in Russia, unlike Poland or Romania, greater presence of foreign capital is associated with higher labor intensity and lower capital intensity of domestic firms. It appears that in this country foreign firms are attracted to more labor-intensive parts of the economy and, when and where they become dominant, they cause domestic firms to become even more labor-intensive. This result may reflect the adjustment strategy of local firms that focus on serving the less well-off segments of the population, instead of competing directly with the far more productive foreign firms. A contributing factor may be that Russian firms benefit less from outsourcing, than do firms in Poland and Romania. We suspect that foreign firms in Russia outsource much less to local producers and, if outsourcing does take place, only relatively simple and more labor-intensive products are outsourced. While in Poland and Romania many of the domestic firms, remaining in the sectors and regions dominated by foreigners, work as their suppliers, in Russia, the remaining domestic firms end up shifting their production to less sophisticated and more labor-intensive goods.

To study the role of education and institutions on the spillover effect in the dynamic setting, we ran the estimations from Table 12 and Table 13 separately for low-education and higheducation regions, as well as for high-corruption and low-corruption regions in Russia. We obtained few clear-cut results, except in the case of Romania. ${ }^{16}$ For that country, our findings are reported in Tables 14 and 15. It turns out that the negative effect of FDI DENSITY is statistically significant only in the low-education regions, while the positive effect of FDI TFP is statistically

\footnotetext{
${ }^{16}$ For the other countries the results were either very similar for both sub-samples (Russia and Ukraine) or statistically insignificant (Poland). In addition, a number of these estimations failed the Hansen test for overidentification, which put into question the reliability of these particular findings.
} 
significant only in the high-education regions. These observations hold for both, the productivity and the capitallabor ratio of domestic firms, and support the view that absorptive capacity, as proxied by education, is clearly important for reaping benefits from FDI.

To summarize, we find strong evidence showing that productivity of foreign firms matters: productivity and capital intensity of domestic firms in the following year are higher where foreign firms are more productive, holding their density constant. This beneficial effect on domestic producers is concentrated in regions with more educated populations, as the Romanian case demonstrates. In contrast, productivity and capital intensity of domestic firms in the following year tend to be lower where foreign firms are more abundant, likely due to increased competition. This detrimental effect is concentrated in low-education regions in Romania, underscoring the importance of absorptive capacity of domestic producers. There is also some evidence of threshold effects: in some countries (Romania) the negative impact of foreign presence is much smaller in sectors and regions where foreign companies dominate, while in other countries (Russia) this negative impact tends to be concentrated exactly where foreign capital is abundant.

\section{Conclusions}

The literature on FDI and their effects on domestic firms usually concentrates on productivity differences between FDI and domestic firms and on productivity spillovers from FDI to domestic firms. At the same time, theoretical considerations used to justify empirical analyses usually state that FDI should possess different technologies and that their entry should stimulate technological upgrade by domestic firms. Therefore, the theory may be reinterpreted as suggesting that FDI have different production functions than domestic firms and that FDI entry stimulates production function change by domestic firms. In addition, more productive foreign firms with superior technologies should have a larger impact on both, the productivity and the production function, of domestic firms.

This paper looks at the evidence from four transition countries - Russia, Ukraine, Poland, and Romania, - and demonstrates that this new interpretation of the theory is confirmed by the data. In the more developed countries with better institutions and larger FDI inflows (Poland and Romania), foreign presence is associated with higher capital intensity and lower labor intensity 
of domestic firms. Even though foreign entry causes capitallabor ratios to decline initially, further accumulation of foreign capital tends to stimulate production function change by domestic firms toward more capital intensive functions. This threshold effect may reflect better technologies brought in by foreign firms once they become established in the host country, as well as their increased willingness to outsource more sophisticated parts to local producers. Absorptive capacity of domestic firms is also important: the evidence of the production function change toward more capitalintensive technologies is strongest in areas where the labor force is more educated.

In contrast, in the countries with worse institutions and correspondingly smaller FDI inflows $\left(\right.$ Russia $^{17}$ ), foreign presence is associated with lower capital intensity and higher labor intensity of domestic firms. The shift to more labor-intensive technologies happens primarily where foreign capital is more abundant. Domestic firms may choose this adaptation in order to secure a separate market for themselves by specializing in serving relatively poor segments of the population. This effect may also reflect reluctance of foreign firms to outsource anything but the production of simple labor-intensive components to domestic suppliers. The reason for such reluctance may be the lack of confidence in the quality of domestically-produced goods and the ability of local firms to deliver their products on time. The production function effect is observed only in the relatively more educated and the less corrupt regions. In highly corrupt regions, foreign firms do not exhibit any productivity advantage over domestic firms, possibly as a result of the attitude of local authorities, which in turn is lobbied for by domestic producers.

As far as conventional productivity spillovers are concerned, we failed to find evidence of their presence, except in a few special cases. In Romania, foreign presence leads to lower productivity of domestic firms after one year, but this effect is present only in low-education regions and appears to wear out as more foreign capital is accumulated. In Ukraine, foreign presence is associated contemporaneously with higher output of domestic firms in higheducation regions. In Russia, negative spillovers occur in the less corrupt regions, where foreign firms are more than twice as productive as domestic firms. Also, importantly, export-oriented foreign firms in Russia generate positive spillovers on domestic firms. Since such foreign firms bring cutting-edge technologies to host countries, the scope for knowledge spillovers is higher for those domestic firms that compete with or work as suppliers for export-oriented foreigners.

\footnotetext{
${ }^{17}$ The absence of data on capital in the Ukraine makes the analysis of production functions there problematic.
} 
More generally, own productivity of foreign firms matters: domestic companies show higher next-year productivity, as well as larger next-year capital labor ratios, where foreign entrants are more productive. 


\section{References.}

1. Aghion, Philippe, Richard Blundell, Rachell Criffith, Peter Howitt, and Susan Prantl (2004). "Firm Entry, Innovation, and Growth", mimeo Harvard University.

2. Aghion, Philippe; Burgess, Robin; Redding, Stephen and Fabrizio Zilibotti. (2003) "The Unequal Effects of Liberalization: Theory and Evidence from India." Mimeo, Harvard, LSE, and IIES.

3. Aitken, Brian J., and Ann E. Harrison. 1999. Do Domestic Firms Benefit from Foreign Direct Investment? Evidence from Venezuela. American Economic Review 89, no. 3 (June): 605-18.

4. Aizenman Joshua and Mark M. Spiegel (2002). "Institutional Efficiency, Monitoring Costs, and the Investment Share of FDI" NBER Working Paper No. 9324.

5. Arellano, M. and S. Bond (1991). "Some tests of specification for panel data: Monte Carlo evidence and an application to employment equations". Review of Economic Studies, Vol. 58, 277-297.

6. Blalock, Garrick, and Paul J. Gertler (2002). "Firm Capabilities and atechnology Adaptation: Evidence from Foreing Direct Investment in Indonesia". Working Paper, Department of Applied Economics and Management, Cornell University. Ithaca, NY: Cornell University.

7. Blomstrom Magnus and Ari Kokko (2003). "The Economics of Foreign Direct Investment Incentives." NBER Working Paper 9489. Cambridge, MA: National Bureau of Economic Research.

8. Blomström, Magnus, and Ari Kokko (1998). "Multinational Corporations and Spillovers." Journal of Economic Surveys 12, no. 2: 1-31.

9. Blundell, Richard, and Stephen R. Bond (1998). "Initial conditions and moment restrictions in dynamic panel data models". Journal of Econometrics, Vol. 87, 115-143.

10. Danijan, Jose P., Mark Knell, Boris Majcen and Matija Rojec (2003), "The Role of FDI, R\&D Accumulation and Trade in Transferring Technology to Transition Countries: Evidence from Firm Panel Data for Eight Transition Countries," Economic Systems, 27: 189-204.

11. Djankov S., and B. Hoekman (2000), "Foreign Investment and Productivity Growth in Czech Enterprises.", World Bank Economic Review 14, no. 1: 49-64.

12. Findlay R. (1978). "Relative backwardness, direct foreign investment, and the transfer of technology: A simple dynamic model." Quarterly Journal of Economics, Vol 92, Issue 1, 116.

13. Gerschenkron A.(1952). "Economic backwardness in historical perspective", in The progress of underdeveloped areas, B.F. Hoselitz edition, University of Chicago Press, Chicago IL.

14. Haskel, Jonathan E., Sonia C. Pereira, and Matthew J. Slaughter(2002). "Does Inward Foreign Direct Investment Boost the Productivity of Domestic Firms?" NBER Working Paper 8724. Cambridge, MA: National Bureau of Economic Research.

15. Javorcik, Beata Smarzynska and Mariana Spatareanu (2005), "Disentangling FDI Spillover Effects: What do Firm Perceptions Tell Us?" in Does Foreign Direct Investment Promote Development, ed. by Theodore H. Moran, Edward M. Graham and Magnus Blomström. Institute for International Economics.

16. Kathuria, Vinish.(2000). "Productivity Spillovers from Technology Transfer to Indian Manufacturing Firms.” Journal of International Development 12, no. 3: 343-69. 
17. Keane Michael P. (2005) "Comment" in Does Foreign Direct Investment Promote Development, ed. by Theodore H. Moran, Edward M. Graham and Magnus Blomström. Institute for International Economics.

18. Kokko A., (1994). “Technology, market characteristics, and spillovers", Journal of Development Economics, Vol. 43, 279-293.

19. Kokko, Ari, (1996). "Productivity Spillovers from Competition Between Local Firms and Foreign Affiliates." Journal of International Development8, no. 4 (April): 517-30.

20. Konings J. (2001), "The Effect Of Direct Foreign Investment on Domestic Firms.", Economics of Transition, 9(3): 619-633.

21. Lipsey Robert E. (2004). "Home- and Host-Country Effects of Foreign Direct Investment." In Challenges to Globalization, ed., Robert E. Baldwin and L. Alan Winters. Chicago: University of Chicago Press.

22. Lipsey Robert E. and Frederick Sjoholm (2005). "The Impact of Inward FDI on Host Countries: Why Such Different Answers" in Does Foreign Direct Investment Promote Development, ed. by Theodore H. Moran , Edward M. Graham and Magnus Blomström. Institute for International Economics.

23. Markusen J and A. Venables, (1999). "Foreign direct investment as a catalyst to industrial development", European Economic Review, Vol. 43, 335-356.

24. Melitz Mark J. (2005). "Comment" in Does Foreign Direct Investment Promote Development, ed. by Theodore H. Moran, Edward M. Graham and Magnus Blomström. Institute for International Economics.

25. Moran Theodore H. (2005). "How Does FDI Affect Host Country Development? Using Industry Case Studies to Make Reliable Generalizations." in Does Foreign Direct Investment Promote Development, ed. by Theodore H. Moran , Edward M. Graham and Magnus Blomström. Institute for International Economics.

26. Perri Giovanni and Dieter Urban (2004) "Catching up to Foreign Technology? Evidence on the Veblen-Gerschenkron Effect of Foreign Investments.” NBER Working Paper 10893.

27. Rodriguez-Clare, Andres (1996). "Multinationals, Linkages, and Economic Development. " American Economic Review86: 852-73.

28. Sjoholm, Frederik (1999). "Technology Gap, Competition and Spillovers from Direct Foreign Investment: Evidence from Establishment Data." Journal of Development Studies 36, no.1 (October): 53-73.

29. Takii, Sadayukii (2001). "Productivity Spillovers and Characterisrics of Foreign Maltinational Plants in Indonesian Manufacturing 1990-1995.” INCSEAD Working Paper 2001-14. Kitakyushu, Japan: ICSEAD.

30. Todo, Yasuyuki, and Koji Miyamoto (2002). "Knowledge Diffusion from Multinational Enterprises: The Role of Domestic and Foreign Knowledge-Enhancing Activities”. OECD Technical Paper 196. Paris: EOCD Development Centre.

31. Veblen T. (1915). Imperial Germany and the industrial revolution, London, Macmillan.

32. Yudaeva, Ksenia, Konstantin Kozlov, Natalia Melentieva, Natalia Ponomaryova (2003), "Does Foreign Ownership Matter? Russian experience", Economics of Transition, 11 (3) 2003

33. Zukowska-Gagelmann K. (2000), "Productivity Spillovers From Foreign Direct Investment In Poland.", Economic Systems, Vol.24,N.3, pp. 223-256. 
Table 1. Selected Economic Indicators

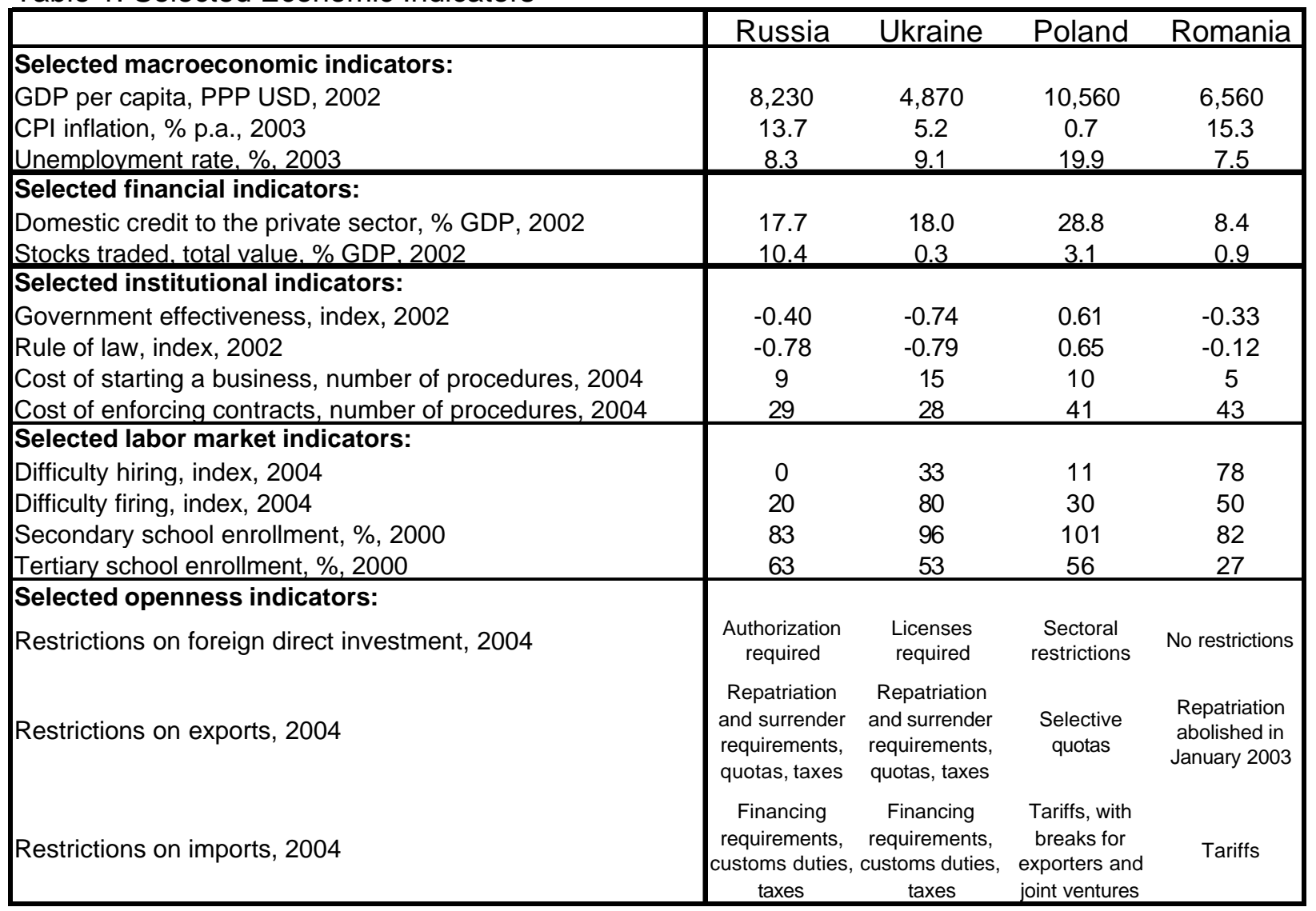

Sources: International Financial Statistics, World Development Indicators, World Bank Governance Database, World Bank Doing Business Database, IMF Annual Report on Exchange Arrangements and Exchange Restrictions

Table 2. Summary of Company Level Data

\begin{tabular}{|c|cc|cc|cc|cc|}
\hline & \multicolumn{2}{|c|}{ Russia } & \multicolumn{2}{c|}{ Ukraine } & \multicolumn{2}{c|}{ Poland } & \multicolumn{2}{c|}{ Romania } \\
\hline Year & $\begin{array}{c}\text { Overall } \\
\text { number of } \\
\text { companies }\end{array}$ & $\begin{array}{c}\text { Percent with } \\
\text { foreign } \\
\text { ownership }\end{array}$ & $\begin{array}{c}\text { Overall } \\
\text { number of }\end{array}$ & $\begin{array}{c}\text { Percent with } \\
\text { foreign } \\
\text { companies }\end{array}$ ownership & $\begin{array}{c}\text { Overall } \\
\text { number of } \\
\text { companies }\end{array}$ & $\begin{array}{c}\text { Percent with } \\
\text { foreign } \\
\text { ownership }\end{array}$ & $\begin{array}{c}\text { Overall } \\
\text { number of } \\
\text { companies }\end{array}$ & $\begin{array}{c}\text { Percent with } \\
\text { foreign } \\
\text { ownership }\end{array}$ \\
\hline 1998 & 10,405 & 0.59 & - & - & - & - & - & - \\
1999 & 20,190 & 2.99 & - & - & 4,494 & 18.36 & 8,794 & 23.72 \\
2000 & 12,330 & 1.80 & 11,960 & 2.20 & 4,807 & 18.22 & 9,639 & 25.36 \\
2001 & 20,752 & 3.53 & 11,408 & 2.20 & 5,422 & 18.54 & 10,544 & 26.55 \\
2002 & 17,923 & 4.20 & 10,743 & 2.40 & 4,789 & 19.15 & 10,989 & 26.94 \\
2003 & - & - & 10,315 & 2.50 & 572 & 23.60 & 11,311 & 26.13 \\
\hline Total & 81,600 & 2.91 & 44,426 & 2.30 & 20,084 & 18.71 & 51,277 & 25.83 \\
\hline
\end{tabular}

Sources: National Statistical Authorities (Russia and Ukraine), Amadeus Database (Poland and Romania) 
Table 3. Direct Effect of Foreign Participation

\begin{tabular}{|c|c|c|c|c|}
\hline Dependent variable: Log Value Added & Russia & Ukraine & Poland & Romania \\
\hline Log Employment & $\begin{array}{l}1.114^{* * *} \\
{[0005]}\end{array}$ & $1.143^{* * *}$ & $\begin{array}{l}0.507^{\star * *} \\
{[0.016]}\end{array}$ & $\begin{array}{l}0.672^{* \star *} \\
{[00071}\end{array}$ \\
\hline Log Employment X FDI & $-0.420^{* * *}$ & 0.035 & -0.020 & $-0.073^{\star * *}$ \\
\hline Log Fixed Capital & {$\left[\begin{array}{l}0.052^{* * *} \\
{[0.003]}\end{array}\right.$} & - & $\begin{array}{l}0.298^{* * *} \\
{[0.010]}\end{array}$ & $\begin{array}{l}0.282^{\star * *} \\
{[0.004]}\end{array}$ \\
\hline Log Fixed Capital X FDI & $\begin{array}{l}0.273^{* * *} \\
{[0.016]}\end{array}$ & - & $\begin{array}{l}0.041^{* *} \\
{[0.018]}\end{array}$ & $\begin{array}{l}0.047^{\star * *} \\
{[0.007]}\end{array}$ \\
\hline FDI & $0.532^{* * *}$ & 0.210 & 0.089 & $0.328^{\star * *}$ \\
\hline Year Dummies & {$\left[\begin{array}{l}{[0.09 /]} \\
\text { yes }\end{array}\right.$} & $\begin{array}{l}{[0.1 / 0]} \\
\text { ves }\end{array}$ & $\begin{array}{l}{[0.132]} \\
\text { yes }\end{array}$ & $\begin{array}{l}{[0.039]} \\
\text { ves }\end{array}$ \\
\hline Sector Dummies & yes & yes & yes & yes \\
\hline Region Dummies & yes & yes & yes & yes \\
\hline $\mathrm{N}$ & 62305 & 38558 & 9435 & 47114 \\
\hline R2 & 0.742 & 0.625 & 0.646 & 0.765 \\
\hline
\end{tabular}

${ }^{*}$ significant at 10\%; ${ }^{\star *}$ significant at $5 \% ;{ }^{* \star \star}$ significant at $1 \%$; robust standard errors in brackets

Table 4. FDI DENSITY by Industrial Sector

\begin{tabular}{|l|c|cccc|}
\hline INDUSTRIAL SECTOR & NACE1.1 & Russia & Ukraine & Poland & Romania \\
\hline Foods and beverages & 15 & 0.03 & 0.06 & 0.07 & 0.17 \\
Tobacco products & 16 & 0.29 & 0.34 & 0.22 & 0.22 \\
Textiles & 17 & 0.03 & 0.03 & 0.15 & 0.33 \\
Apparel & 18 & 0.03 & 0.05 & 0.11 & 0.28 \\
Leather & 19 & 0.05 & 0.05 & 0.14 & 0.42 \\
Wood products & 20 & 0.05 & 0.07 & 0.25 & 0.25 \\
Paper & 21 & 0.13 & 0.11 & 0.33 & 0.27 \\
Publishing & 22 & 0.01 & 0.01 & 0.19 & 0.17 \\
Chemicals & 24 & 0.07 & 0.07 & 0.14 & 0.19 \\
Rubber and plastics & 25 & 0.06 & 0.05 & 0.31 & 0.21 \\
Other non-metals & 26 & 0.06 & 0.04 & 0.19 & 0.13 \\
Basic metals & 27 & 0.11 & 0.10 & 0.18 & 0.31 \\
Metal products & 28 & 0.01 & 0.05 & 0.09 & 0.08 \\
Machinery & 29 & 0.03 & 0.04 & 0.12 & 0.19 \\
Office equipment & 30 & 0.10 & 0.00 & 0.08 & 0.11 \\
Electrical equipment & 31 & 0.05 & 0.04 & 0.42 & 0.23 \\
Communication equipment & 32 & 0.00 & 0.06 & 0.45 & 0.41 \\
Precision instruments & 33 & 0.04 & 0.04 & 0.17 & 0.12 \\
Motor vehicles & 34 & 0.04 & 0.13 & 0.41 & 0.26 \\
Other transport equipment & 35 & 0.03 & 0.06 & 0.15 & 0.17 \\
Furniture & 36 & 0.04 & 0.02 & 0.42 & 0.12 \\
Recycling & 37 & 0.09 & 0.07 & 0.16 & 0.20 \\
\hline Total & & 0.06 & 0.07 & 0.21 & 0.22 \\
\hline
\end{tabular}


Table 5. Static Specification with FDI DENSITY

\begin{tabular}{|c|c|c|c|c|}
\hline Dependent variable: Log Value Added & Russia & Ukraine & Poland & Romania \\
\hline \multirow{2}{*}{ Log Employment } & $0.932^{* * *}$ & $1.018^{* * *}$ & $0.318^{* * *}$ & $0.624^{* * *}$ \\
\hline & {$[0.019]$} & [0.035] & [0.025] & [0.020] \\
\hline \multirow{2}{*}{ Log Fixed Capital } & $0.191^{\star \star \star}$ & - & $0.335^{\star \star *}$ & $0.325^{\star * *}$ \\
\hline & {$[0.013]$} & & [0.017] & [0.014] \\
\hline \multirow{2}{*}{ FDI DENSITY } & $0.779^{\star \star \star}$ & $0.960^{\star \star *}$ & -0.073 & $-0.124^{\star \star *}$ \\
\hline & {$[0.196]$} & [0.352] & [0.062] & {$[0.046]$} \\
\hline $\mathrm{N}$ & 5995 & 2163 & 1320 & 3755 \\
\hline $\mathrm{R} 2$ & 0.722 & 0.357 & 0.636 & 0.764 \\
\hline \multicolumn{5}{|l|}{ Panel B: Panel estimation with firm fixed effects } \\
\hline Dependent variable: Log Value Added & Russia & Ukraine & Poland & Romania \\
\hline Log Employment & $\begin{array}{l}0.784^{* * *} \\
{[0.017]}\end{array}$ & $\begin{array}{l}0.945^{* * *} \\
{[0.018]}\end{array}$ & $\begin{array}{l}0.392^{* * *} \\
{[0.063]}\end{array}$ & $\begin{array}{l}0.604^{* \star *} \\
{[0.015]}\end{array}$ \\
\hline Log Fixed Capital & 0.009 & - & $0.191^{* * *}$ & $0.196^{\star * \star}$ \\
\hline \multirow{2}{*}{ FDI DENSITY } & {$\left[\begin{array}{ll}0.010 \\
-0.027\end{array}\right.$} & 0.068 & 0.148 & 0.023 \\
\hline & {$[0.094]$} & [0.273] & [0.096] & [0.055] \\
\hline Year and Firm Fixed Effects & yes & yes & yes & yes \\
\hline \multirow{3}{*}{$\begin{array}{l}\text { N groups } \\
\text { N observations } \\
\text { R2 }\end{array}$} & 20289 & 13548 & 3300 & 8497 \\
\hline & 60429 & 37628 & 7483 & 35252 \\
\hline & 0.148 & 0.320 & 0.126 & 0.550 \\
\hline \multicolumn{5}{|c|}{ Panel C: Panel estimation with heterogeneous production functions } \\
\hline Dependent variable: Log Value Added & Russia & Ukraine & Poland & Romania \\
\hline Log Employment X FDI DENSITY & $0.201^{* *}$ & $\begin{array}{l}-0.142 \\
\end{array}$ & $-0.356^{* *}$ & $\begin{array}{l}-0.052 \\
\end{array}$ \\
\hline \multirow{2}{*}{ Log Fixed Capital X FDI DENSITY } & $-0.163^{* *}$ & & $0.213^{*}$ & 0.008 \\
\hline & {$[0.067]$} & & {$[0.110]$} & {$[0.029]$} \\
\hline Log Employment X Sector & yes & yes & yes & yes \\
\hline Log Fixed Capital X Sector & yes & - & yes & yes \\
\hline FDI DENSITY X Sector & yes & yes & yes & yes \\
\hline Year and Firm Fixed Effects & yes & yes & yes & yes \\
\hline \multirow{3}{*}{$\begin{array}{l}\text { N groups } \\
\text { N observations } \\
\text { R2 }\end{array}$} & 20289 & 13490 & 3300 & 8497 \\
\hline & 60429 & 37424 & 7483 & 35252 \\
\hline & 0.153 & 0.327 & 0.170 & 0.556 \\
\hline
\end{tabular}

* significant at 10\%; ${ }^{\star *}$ significant at $5 \%$; ${ }^{\star \star *}$ significant at 1\%; robust st. errors in brackets; p-values in parentheses 
Table 6. IV Estimation for Poland Dependent variable: Log Value Added

\begin{tabular}{|l|l|}
\hline Log Employment & $0.373^{\star \star \star}$ \\
Log Fixed Capital & {$[0.032]$} \\
FDI DENSITY & $0.195^{\star * \star}$ \\
Year and Firm Fixed Effects & {$[0.017]$} \\
\hline First Stage F Test & {$[0.982$} \\
N groups & {$[0.990]$} \\
yes & 9.75 \\
\hline observations & $(0.00)$ \\
\hline
\end{tabular}

Table 7. Role of exporting FDI in Russia Dependent variable: Log Value Added

\begin{tabular}{|l|l|}
\hline Log Employment & $0.785^{\star * \star}$ \\
Log Fixed Capital & {$[0.017]$} \\
& 0.009 \\
FDI DENSITY & {$[0.010]$} \\
& -0.120 \\
EXPORT-ORIENTED FDI DENSITY & {$[0.106]$} \\
$0.386^{\star}$ \\
Year and Firm Fixed Effects & {$[0.210]$} \\
\hline N groups & yes \\
N observations & 20289 \\
R2 & 60429 \\
\hline
\end{tabular}


Table 8. Education and Direct Effects of Foreign Participation Panel A: Bottom 1/3 of regions by share of people with secondary education

\begin{tabular}{|c|c|c|c|c|}
\hline Dependent variable: Log Value Added & Russia & Ukraine & Poland & Romania \\
\hline Log Employment & $1.135^{\star \star \star}$ & $1.221^{* \star \star}$ & $0.476^{\star \star *}$ & $0.652^{\star \star *}$ \\
\hline & {$[0.011]$} & [0.012] & [0.027] & {$[0.010]$} \\
\hline Log Employment X FDI & $-0.504^{\star * *}$ & 0.008 & -0.005 & $-0.099^{\star \star \star}$ \\
\hline I og Fixed Canital & $0.039^{* * *}$ & & $0.322^{\star \star *}$ & $0.284^{\star \star *}$ \\
\hline Log rixed vapital & {$[0.006]$} & & {$[0.017]$} & {$[0.007]$} \\
\hline Log Fixed Capital X FDI & $0.292^{* * *}$ & - & -0.004 & $0.071^{* * *}$ \\
\hline & [0.044] & & {$[0.034]$} & [0.012] \\
\hline FDI & $0.857^{\star \star \star}$ & $\begin{array}{l}0.301 \\
503891\end{array}$ & $0.505^{\star *}$ & $0.352^{* * *}$ \\
\hline Year Dummies & yes & yes & yes & [0.000] \\
\hline Sector Dummies & yes & yes & yes & yes \\
\hline Region Dummies & yes & yes & yes & yes \\
\hline $\mathrm{N}$ & 19642 & 13705 & 3115 & 17298 \\
\hline R2 & 0.762 & 0.608 & 0.635 & 0.752 \\
\hline \multicolumn{5}{|c|}{ Panel B: Top $1 / 3$ of regions by share of people with secondary education } \\
\hline Dependent variable: Log Value Added & Russia & Ukraine & Poland & Romania \\
\hline \multirow[t]{3}{*}{ Log Employment } & $1.086^{* * *}$ & $1.032^{* \star *}$ & $0.535^{\star \star \star}$ & $0.661^{* \star *}$ \\
\hline & {$\left[\begin{array}{ll}0.0111 \\
-0.387^{* * *}\end{array}\right.$} & $\begin{array}{l}{[0.012]} \\
-0.018\end{array}$ & $\begin{array}{l}{[0.026]} \\
-0.053\end{array}$ & $\begin{array}{l}{[0.012]} \\
-0.048^{* *}\end{array}$ \\
\hline & {$[0.048]$} & [0.051] & {$[0.037]$} & [0.022] \\
\hline Log Fixed Capital & $0.063^{* * *}$ & - & $0.277^{* \star *}$ & $0.295^{* * *}$ \\
\hline \multirow{2}{*}{ Log Fixed Capital X FDI } & {$[0.001]$} & - & $\begin{array}{l}{[0.016]} \\
0.089^{* \star *}\end{array}$ & $\begin{array}{l}{[0.008]} \\
0.028^{* *}\end{array}$ \\
\hline & {$[0.029]$} & & {$[0.026]$} & {$[0.013]$} \\
\hline \multirow{2}{*}{ FDI } & $0.585^{\star \star \star}$ & $0.719^{* *}$ & -0.166 & $0.297^{* * *}$ \\
\hline & {$[0.166]$} & [0.329] & {$[0.177]$} & [0.064] \\
\hline $\begin{array}{l}\text { Year Dummies } \\
\text { Sector Dummies }\end{array}$ & yes & & yes & yes \\
\hline Sector Dummies & yes & & yes & yes \\
\hline \multirow{2}{*}{$\frac{\text { Region Dummies }}{\mathrm{N}}$} & yes & & yes & yes \\
\hline & 20845 & 12789 & 4121 & 17411 \\
\hline R2 & 0.719 & 0.602 & 0.658 & 0.777 \\
\hline
\end{tabular}

* significant at 10\%; ${ }^{* *}$ significant at 5\%; ${ }^{* *}$ significant at $1 \%$; robust standard errors in brackets 
Table 9. Education and Spillover Effects of Foreign Participation Panel A: Bottom 1/3 of regions by share of people with secondary education

\begin{tabular}{|c|c|c|c|c|}
\hline Dependent variable: Log Value Added & Russia & Ukraine & Poland & Romania \\
\hline FDI DENSITY & $\begin{array}{l}-0.230 \\
{[0.3271}\end{array}$ & $\begin{array}{l}-2.912 \\
{[2.4401}\end{array}$ & $\begin{array}{l}-0.352 \\
{[0.490]}\end{array}$ & $\begin{array}{l}0.114 \\
{[0.331]}\end{array}$ \\
\hline Log Emolovment X FDI DENSITY & 0.051 & 0.750 & 0.016 & 0.027 \\
\hline 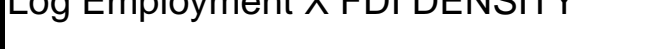 & {$[0.153]$} & [0.509] & {$[0.120]$} & [0.101] \\
\hline Log Fixed Capital X FDI DENSITY & $\begin{array}{l}0.006 \\
{[0.089]}\end{array}$ & & $\begin{array}{l}0.060 \\
{[0.068]}\end{array}$ & $\begin{array}{l}-0.043 \\
{[0.055]}\end{array}$ \\
\hline Log Employment X Sector & yes & yes & yes & yes \\
\hline Log Fixed Capital X Sector & yes & - & yes & yes \\
\hline Year and Firm Fixed Effects & yes & yes & yes & yes \\
\hline $\mathrm{N}$ groups & 6339 & 4773 & 1108 & 3200 \\
\hline $\mathrm{N}$ observations & 19172 & 13378 & 2502 & 13078 \\
\hline & 0.145 & 0.302 & 0.191 & 0.537 \\
\hline \multicolumn{5}{|c|}{ Panel B: Top $1 / 3$ of regions by share of people with secondary education } \\
\hline Dependent variable: Log Value Added & Russia & Ukraine & Poland & Romania \\
\hline FDI DENSITY & $\begin{array}{l}-0.277 \\
{[0.676]}\end{array}$ & $\begin{array}{l}4.148^{*} \\
{[2.405]}\end{array}$ & $\begin{array}{l}0.026 \\
{[0.473]}\end{array}$ & $\begin{array}{l}-0.105 \\
{[0.263]}\end{array}$ \\
\hline Log Employment X FDI DENSITY & $\begin{array}{l}0.412^{\star * *} \\
{[0.149]}\end{array}$ & $\begin{array}{l}-0.964^{*} \\
{[0.506]}\end{array}$ & $\begin{array}{l}-0.410^{* *} \\
{[0.172]}\end{array}$ & $\begin{array}{l}-0.033 \\
{[0.086]}\end{array}$ \\
\hline Log Fixed Capital X FDI DENSITY & $-0.244^{\star \star *}$ & & $0.300^{* * *}$ & 0.046 \\
\hline & {$[0.093]$} & & [0.116] & [0.044] \\
\hline Log Employment X Sector & yes & yes & yes & yes \\
\hline Log Fixed Capital X Sector & yes & - & yes & yes \\
\hline Year and Firm Fixed Effects & yes & yes & yes & yes \\
\hline N groups & 6670 & 4501 & 1367 & 3099 \\
\hline N observations & 19869 & 12448 & 3183 & 13020 \\
\hline R2 & 0.166 & 0.361 & 0.253 & 0.580 \\
\hline
\end{tabular}

${ }^{*}$ significant at $10 \%$; ${ }^{* *}$ significant at $5 \%$; ${ }^{* *}$ significant at $1 \%$; robust standard errors in brackets 
Table 10. Corruption and Direct Effects of FDI in Russia

\begin{tabular}{|c|c|c|}
\hline Dependent variable: Log Value Added & $\begin{array}{l}1 / 3 \text { with } \\
\text { high } \\
\text { corruption }\end{array}$ & $\begin{array}{l}1 / 3 \text { with } \\
\text { low } \\
\text { corruption }\end{array}$ \\
\hline Log Employment & $1.093^{\star \star \star}$ & $1.122^{\star * \star}$ \\
\hline & {$[0.012]$} & {$[0.013]$} \\
\hline Log Employment X FDI & $\begin{array}{l}-0.516 \\
{[0.073]}\end{array}$ & $\begin{array}{l}-0.336 \\
{[0.053]}\end{array}$ \\
\hline Log Fixed Capital & $\begin{array}{l}0.058^{\star \star \star *} \\
{[0.007]}\end{array}$ & $\begin{array}{l}0.048^{\star \star \star} \\
{[0.008]}\end{array}$ \\
\hline Log Fixed Capital X FDI & {$\left[\begin{array}{l}0.375^{\star * \star} \\
{[0.045]}\end{array}\right.$} & $\begin{array}{l}0.194^{\star * \star} \\
{[0.034]}\end{array}$ \\
\hline FDI & $\begin{array}{l}0.110 \\
\ln 2561\end{array}$ & $\begin{array}{l}0.817^{* * *} \\
{[01961}\end{array}$ \\
\hline Year Dummies & yes & yes \\
\hline Sector Dummies & yes & yes \\
\hline Region Dummies & yes & yes \\
\hline $\mathrm{N}$ & 14799 & 13709 \\
\hline $\mathrm{R} 2$ & 0.712 & 0.757 \\
\hline
\end{tabular}

Table 11. Corruption and Spillover Effects of FDI in Russia

\begin{tabular}{|l|ll|}
\hline Dependent variable: Log Value Added & $\begin{array}{ll}\mathbf{1 / 3} \text { with } & \mathbf{1 / 3} \text { with } \\
\text { high } & \text { low } \\
\text { corruption } & \text { corruption }\end{array}$ \\
\hline FDI DENSITY & -0.341 & $-0.874^{*}$ \\
& {$[0.745]$} & {$[0.456]$} \\
Log Employment X FDI DENSITY & 0.098 & $0.468^{\star *}$ \\
Log Fixed Capital X FDI DENSITY & {$[0.169]$} & {$[0.216]$} \\
& -0.049 & -0.185 \\
Log Employment X Sector & {$[0.103]$} & {$[0.114]$} \\
Log Fixed Capital X Sector & yes & yes \\
Year and Firm Fixed Effects & yes & yes \\
\hline N groups & yes & yes \\
N observations & 4743 & 4476 \\
R2 & 14346 & 13138 \\
\hline
\end{tabular}


Table 12. Dynamic Specification with FDI TFP and FDI DENSITY

\begin{tabular}{|c|c|c|c|c|}
\hline \multicolumn{5}{|l|}{ Panel A: Basic specification } \\
\hline Dependent variable: TFP & Russia & Ukraine & Poland & Romania \\
\hline Lagged TFP & $0.712^{* * *}$ & $0.983^{\star * *}$ & 0.285 & $0.606^{\star * *}$ \\
\hline Lati & {$[0.067]$} & [0.080] & [0.335] & [0.064] \\
\hline Lagged FDI TFP & $0.254^{* \star *}$ & 0.002 & 0.006 & $0.088^{* * *}$ \\
\hline & {$[0.059]$} & [0.030] & [0.128] & {$[0.030]$} \\
\hline Lagged FDI DENSITY & -0.250 & 0.082 & -0.669 & $-0.526^{\star * *}$ \\
\hline Year Dummies & yes & yes & yes & yes \\
\hline Sector Dummies & yes & yes & yes & yes \\
\hline Region Dummies & yes & yes & yes & yes \\
\hline N groups & 5038 & 5349 & 1499 & 6832 \\
\hline N observations & 7938 & 11912 & 2902 & 21715 \\
\hline Hansen Chi2 Overid Test & 7.80 & 9.41 & 5.26 & 6.62 \\
\hline Arollano-Rond $\Delta \mathrm{R}(1)$ Tect & $\begin{array}{l}(0.453) \\
-6.09\end{array}$ & -10.09 & $\begin{array}{l}(.730) \\
-1.24\end{array}$ & -9.42 \\
\hline Arellano-bond AR(I) Iest & $(0.000)$ & $(0.000)$ & $(0.213)$ & $(0.000)$ \\
\hline Arellano-Bond AB(2) Test & -0.93 & - & -1.36 & 0.77 \\
\hline Aremano-Doma & $(0.352)$ & - & $(0.173)$ & $(0.442)$ \\
\hline \multicolumn{5}{|c|}{ Panel B: Specification with threshold effects } \\
\hline Dependent variable: TFP & Russia & Ukraine & Poland & Romania \\
\hline \multirow{2}{*}{ Lagged TFP } & $0.717^{\star \star *}$ & $0.981^{\star * *}$ & 0.361 & $0.598^{\star \star \star}$ \\
\hline & {$[0.066]$} & [0.081] & [0.285] & [0.065] \\
\hline \multirow[t]{2}{*}{ Lagged FDI TFP } & $0.248^{* * *}$ & -0.002 & -0.022 & $0.108^{\star \star * *}$ \\
\hline & {$[0.057]$} & [0.030] & [0.110] & [0.033] \\
\hline Lagged FDI DENSITY & $\begin{array}{l}0.246 \\
{[0.359]}\end{array}$ & $\begin{array}{l}-0.323 \\
{[0.585]}\end{array}$ & $\begin{array}{l}-0.338 \\
{[1.166]}\end{array}$ & $\begin{array}{l}-1.052^{\star \star \star} \\
{[0.3081}\end{array}$ \\
\hline \multirow{2}{*}{ Lagged FDI DENSITY over 50\% } & -1.404 & 0.586 & -0.040 & $0.686^{* \star *}$ \\
\hline & {$[1.080]$} & [0.528] & [0.669] & {$[0.235]$} \\
\hline \multirow{2}{*}{$\begin{array}{l}\text { Year Dummies } \\
\text { Sector Dummies }\end{array}$} & yes & yes & yes & yes \\
\hline & yes & yes & yes & yes \\
\hline Region Dummies & yes & yes & yes & yes \\
\hline \multirow{2}{*}{$\begin{array}{l}\mathrm{N} \text { groups } \\
\mathrm{N} \text { observations }\end{array}$} & 5038 & 5349 & 1499 & 6832 \\
\hline & 7938 & 11912 & 2902 & 21715 \\
\hline \multirow{2}{*}{ Hansen Chi2 Overid Test } & 11.25 & 10.34 & 8.66 & 14.74 \\
\hline & $(0.508)$ & $(0.016)$ & $(0.731)$ & $(0.256)$ \\
\hline Arellano-Bond AR(1) Test & -6.08 & -10.07 & $\begin{array}{l}-1.67 \\
(0.095)\end{array}$ & $\begin{array}{l}-9.32 \\
(0.000)\end{array}$ \\
\hline \multirow{2}{*}{ Arellano-Bond AR(2) Test } & -0.69 & - & -1.40 & 0.76 \\
\hline & $(0.491)$ & - & $(0.161)$ & $(0.448)$ \\
\hline
\end{tabular}

* significant at $10 \%$; ** significant at $5 \%$; ** significant at $1 \%$; robust st.errors in brackets; $p$-values in parentheses Notes: TFP and FDI DENSITY are assumed endogenous and instrumented by lags (starting from the third lag) 
Table 13. Dynamic Specification for Capital-Labor Ratios

\begin{tabular}{|c|c|c|c|c|}
\hline \multicolumn{5}{|l|}{ Panel A: Basic specification } \\
\hline Dependent variable: Log K/L & Russia & Ukraine & Poland & Romania \\
\hline Lagged Log K/L & $0.940^{* * *}$ & - & $0.939^{* * *}$ & $0.753^{* \star *}$ \\
\hline & [0.038] & - & [0.159] & [0.028] \\
\hline Lagged FDI TFP & -0.002 & - & $0.311^{*}$ & $0.075^{\star}$ \\
\hline & {$[0.004]$} & - & [0.161] & [0.044] \\
\hline Lagged FDI DENSITY & -0.079 & - & $-3.488^{* *}$ & $-0.596^{* *}$ \\
\hline Year Dummies & yes & - & yes & yes \\
\hline Sector Dummies & yes & - & yes & yes \\
\hline Region Dummies & yes & - & yes & yes \\
\hline $\mathrm{N}$ groups & 5043 & - & 1506 & 6861 \\
\hline N observations & 7947 & - & 2913 & 21948 \\
\hline Hansen Chi2 Overid Test & 19.36 & - & 3.41 & 10.94 \\
\hline & $(0.013)$ & - & $(0.906)$ & $(0.205)$ \\
\hline Arellano-Bond AR(1) Test & -4.88 & - & -3.07 & -12.05 \\
\hline & $(0.000)$ & - & $(0.002)$ & $(0.000)$ \\
\hline Arellano-Bond AR(2) Test & -1.00 & - & -1.48 & -0.17 \\
\hline \multirow{2}{*}{\multicolumn{5}{|c|}{ Panel B: Specification with threshold effects }} \\
\hline & & & & \\
\hline Dependent variable: Log K/L & Russia & Ukraine & Poland & Romania \\
\hline \multirow{2}{*}{ Lagged Log K/L } & $0.935^{\star \star \star}$ & - & $0.920^{\star \star \star}$ & $0.752^{\star \star \star}$ \\
\hline & [0.038] & - & [0.172] & [0.029] \\
\hline \multirow{2}{*}{ Lagged FDI TFP } & -0.003 & - & $0.288^{*}$ & $0.129^{\star *}$ \\
\hline & {$[0.004]$} & - & [0.163] & [0.053] \\
\hline Lagged FDI DENSITY & $\begin{array}{l}0.129 \\
{[0.205]}\end{array}$ & - & $\begin{array}{l}-3.344^{*} \\
{[1.9221}\end{array}$ & $\begin{array}{l}-1.638^{\star \star \star} \\
{[0.5871}\end{array}$ \\
\hline \multirow{2}{*}{ Lagged FDI DENSITY over 50\% } & $-0.731^{* *}$ & - & 0.238 & $1.123^{* *}$ \\
\hline & {$[0.365]$} & - & [1.686] & [0.474] \\
\hline \multirow{2}{*}{$\begin{array}{l}\text { Year Dummies } \\
\text { Sector Dummies }\end{array}$} & yes & - & yes & yes \\
\hline & yes & - & yes & yes \\
\hline Region Dummies & yes & - & yes & yes \\
\hline \multirow{2}{*}{$\begin{array}{l}\mathrm{N} \text { groups } \\
\mathrm{N} \text { observations }\end{array}$} & 5043 & - & 1506 & 6861 \\
\hline & 7947 & - & 2913 & 21948 \\
\hline \multirow{2}{*}{ Hansen Chi2 Overid Test } & 23.22 & - & 4.12 & 12.35 \\
\hline & $(0.026)$ & - & (0.981) & $(0.418)$ \\
\hline \multirow[t]{2}{*}{ Arellano-Bond AR(1) Test } & -4.87 & - & -3.04 & -12.19 \\
\hline & $(0.000)$ & - & $(0.002)$ & $(0.000)$ \\
\hline \multirow[t]{2}{*}{ Arellano-Bond AR(2) Test } & -0.84 & - & -1.43 & -0.23 \\
\hline & $(0.401)$ & - & $(0.153)$ & $(0.821)$ \\
\hline
\end{tabular}

* significant at 10\%; ** significant at $5 \%$; *** significant at $1 \%$; robust st.errors in brackets; $p$-values in parentheses Notes: Log K/L and FDI DENSITY are assumed endogenous and instrumented by lags (starting from the third lag) 
Table 14. Education and Dynamic Effects of FDI in Romania (1)

\begin{tabular}{|c|c|c|}
\hline Dependent variable: TFP & $\begin{array}{c}\text { low- } \\
\text { education } \\
\text { bottom } 1 / 3\end{array}$ & $\begin{array}{c}\text { high- } \\
\text { education } \\
\text { top } 1 / 3\end{array}$ \\
\hline Lagged TFP & $0.620^{* * *}$ & $0.623^{\star * \star}$ \\
\hline & -2.944 & $0.093^{\star}$ \\
\hline Lagged FDI IFP & {$[0.048]$} & [0.049] \\
\hline Lagged FDI DENSITY & $-0.702^{* * *}$ & -0.245 \\
\hline Year Dummies & $\begin{array}{l}{[0 .<24]} \\
\text { yes }\end{array}$ & yes \\
\hline Sector Dummies & yes & yes \\
\hline Region Dummies & yes & yes \\
\hline $\mathrm{N}$ groups & 2527 & 2548 \\
\hline N observations & 7761 & 8306 \\
\hline Hansen Chi2 Overid Test & $\begin{array}{l}6.19 \\
(0.625)\end{array}$ & $\begin{array}{l}8.32 \\
(0.403)\end{array}$ \\
\hline Arellano-Bond AR(1) Test & -5.71 & -6.19 \\
\hline Arellano-Bond AR(2) Test & 0.53 & 1.06 \\
\hline & $(0.595)$ & $(0.291)$ \\
\hline
\end{tabular}

Table 15. Education and Dynamic Effects of FDI in Romania (2)

\begin{tabular}{|c|c|c|}
\hline Dependent variable: $\log \mathrm{K} / \mathrm{L}$ & $\begin{array}{c}\text { low- } \\
\text { education } \\
\text { bottom } 1 / 3\end{array}$ & $\begin{array}{c}\text { high- } \\
\text { education } \\
\text { top } 1 / 3\end{array}$ \\
\hline Lagged Log K/L & $0.713^{\star \star \star}$ & $0.739^{* \star *}$ \\
\hline I agaed FDI TFP & 0.078 & $0.121^{\star}$ \\
\hline Laggea rDI I & {$[0.066]$} & [0.073] \\
\hline Lagged FDI DENSITY & $-0.829^{* *}$ & -0.612 \\
\hline Year Dummies & yes & yes \\
\hline Sector Dummies & yes & yes \\
\hline Region Dummies & yes & yes \\
\hline $\mathrm{N}$ groups & 2536 & 2560 \\
\hline N observations & 7843 & 8393 \\
\hline \multirow{3}{*}{ Arellano-Bond AR(1) Test } & $\begin{array}{l}12.69 \\
0.123)\end{array}$ & $\begin{array}{l}6.93 \\
(0.544)\end{array}$ \\
\hline & -7.63 & -6.71 \\
\hline & $(0.000)$ & $(0.000)$ \\
\hline Arellano-Bond AR(2) Test & $\left|\begin{array}{l}-0.48 \\
(0.628)\end{array}\right|$ & $\begin{array}{l}0.32 \\
(0.747)\end{array}$ \\
\hline
\end{tabular}

